\title{
EARLY RISK STRATIFICATION IN ACUTE PANCREATITIS: THE ROLE OF BIOCHEMICAL AND HEMATOLOGICAL PARAMETERS
}

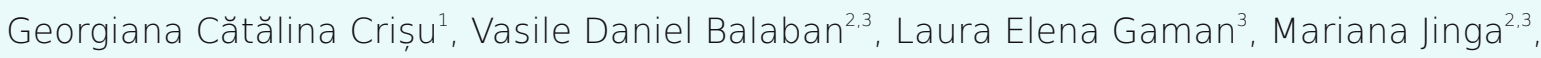 \\ Flavius Stefan Marin², Irina Stoian³, Valeriu Atanasiu ${ }^{3}$ \\ ${ }^{1}$ County Emergency Hospital of Ploiești \\ 2"Dr Carol Davila" Central Emergency University Military Hospital \\ "Carol Davila" University of Medicine and Pharmacy \\ Corresponding author: Laura Elena Gaman \\ E-mail:glauraelena@yahoo.com
}

\begin{abstract}
Acute pancreatitis $(A P)$ represents an inflammatory condition,-with a wide spectrum of local and systemic complications. Early stratification of severity of pancreatitis is an important step in guiding the management of the disease and improving outcomes. Throughout the years many researchers have looked at various risk stratification parameters which could be used from the admission of patients, however current available scores are cumbersome.

Our aim was to evaluate the role of biochemical and hematological parameters in the early stratification of severity of $A P$, regarding the length of hospitalization.

We conducted an observational study which included 100 patients with AP admitted to the Gastroenterology Department over a period 18 months. AP diagnosis was set according to 2013 ACG criteria. Demographic, clinical and imaging data related to the pancreatitis flare were collected from their charts. Length of hospital stay was used as surrogate marker for severity of AP. We evaluated different biochemical and hematological parameters which influenced the length of hospitalization.

Several hematological parameters and ratio did not correlate with length of hospital stay in our study cohort, however there was a significant relation of hyperglycemia and alkaline phosphatase levels with hospitalization duration.

Early risk stratification in AP remains difficult with routine blood work done at admission. Glycemic control and serum level of alkaline phosphatase seems to be correlated with length of hospital stay.
\end{abstract}

Keywords: biochemical parameters, hematological, acute pancreatitis, severity. 


\section{INTERNAL}

\section{Original papers}

\section{Rezumat}

Pancreatita reprezintă o condiție inflamatorie, ce poate determina diverse complicații locale și sistemice. Stratificarea severității pancreatitei acute reprezintă un pas important în stabilirea managementului bolii. De aceea, de-a lungul anilor, s-au folosit mai multe scoruri și parametri ce pot fi aplicați încă de la admisia pacientului în spital.

Scopul nostru a fost să evaluăm impactul parametrilor biochimici și hematologici asupra stratificării precoce a severității pancreatitei acute, în relație cu durata de spitalizare.

Am inclus în studiu 100 de pacienți, pe o perioada de 18 luni, diagnosticti cu pancreatita acută admiși pe secția de gastroenterologie. Diagnosticul pancreatitei acute s-a realizat conform criteriilor ACG 2013. Au fost înregistrate date demografice, clinice și imagistice ale pacientilor. Am folosit drept factor de risc al severității pancreatitei acute durata spitalizării. Am evaluat diferiți parametri și corelații ce puteau influența durata spitalizării.

în studiul nostru parametrii hematologici nu au influențat durata spitalizării, în schimb am observat o influență a hiperglicemiei și fosfatazei alkaline asupra acestui marker al severității. Stadializarea precoce a pancreatitei acute pe baza parametrilor obișnuiți rămâne dificilă. Valoarea glicemiei și a fosfatazei alkaline pare să se asocieze cu durata de spitalizare.

Cuvinte cheie: parametri biochimici, hematologici, pancreatita acută, severitate.

\section{Introduction}

Acute pancreatitis (AP) represents one of the most common gastrointestinal emergencies and is characterized by an inflammatory process of the pancreas with different grades of severity ${ }^{(1)}$. This inflammatory condition is initiated by the loss of balance between protective enzymes and stress signals ${ }^{(2,3)}$. It determines pancreatic or peripancreatic lesions, such as edema, necrosis or hemorrhagic necrosis ${ }^{(4)}$. Gallstones and alcohol represent the most two common causes of AP. Drugs or gene mutations can also cause an AP flare ${ }^{(5,6,7)}$, while some particular etiologies such as hypertriglyceridemia can be associated with severe complications ${ }^{(8)}$.

Diagnosis of acute pancreatitis is based on combination of clinical symptoms such as abdominal pain, nausea, laboratory enzymes (levels of lipase, amylase three times than 
the upper limit of normal) and imaging findings ${ }^{(9,10)}$.

AP is now recognized as a systemic disease which can develop significant complications and the clinical course can be unpredictable. AP ranges from mild to severe forms ${ }^{(11)}$ and patients can deteriorate rapidly in the disease course. In moderate-severe and severe forms it can determine transient or persistent multiple organ failure, such as cardiovascular, renal and respiratory ${ }^{(12,13)}$.

It is very helpful to recognize the severity of pancreatitis from the onset as the optimization of therapy could be better. Nowadays there are several severity scoring systems $^{(14)}$ such as acute physiology and chronic health evaluation II (APACHE II) system, Ranson criteria and bedside index for severity in acute pancreatitis (BISAP) score. Recently, a predictive score for mortality used in $A P$ is the sequential organ failure assessment (SOFA) score ${ }^{(15,16,17)}$. New biomarkers using combined laboratory tests such as neutrophil- lymphocyte ratio (NLR), platelet-lymphocyte ratio (PLR) and red cell distribution width (RDW) have been evaluated as prognostic factors for the severity of pancreatitis ${ }^{(18,19)}$. NLR represents a promising test for predicting the severity of hypertriglyceridemia - induced acute pancreatitis ${ }^{(20)}$.

The aim of the current study was to evaluate the impact of biochemical and hematological parameters for early stratification of AP severity.

\section{Material and methods}

We included in our study patients admitted in the Gastroenterology Department with AP, over a period of 18 months. AP diagnosis was set according to currently available guidelines, on the two of the three criteria (clinical, biochemical and imaging). We have stratified the severity of AP upon the length of hospitalization.

We recorded demographic and clinical information, also laboratory parameters for each patient enrolled in the study. We evaluated blood cell count, serum glucose, neutrophil to lymphocyte ratio (NLR), platelet to lymphocyte ratio (PLR), red blood cell distribution width (RDW), amylase, lipase, transaminases, alkaline phosphatase, C reactive protein (CRP), total bilirubin. All these parameters were done from the admission.

We determined the impact of these parameters for early stratification of severity of acute pancreatitis as determined by length of hospitalization. Discharge criteria were improvement/remission of abdominal pain, re-start and well tolerated oral feeding and sustained, decreasing CRP.

Statistical analysis was performed by using $R$ programming software, version 3.5.3. Results are presented as mean \pm standard deviation for numeric variables and percentage for categorical variables. We used Shapiro Wilk test to assess normality of distribution. Pearson correlation was used for testing association between hematological/ biochemical parameters and length of hospitalization.

Local ethics committee approval was obtained was obtained for this study.

\section{Results}

We enrolled 100 patients with a mean age of $58 \pm 15$ years and a male predominance ( $65 \%$ of the study cohort). Most of the patients were from the urban environment. The etiology of AP was biliary $(46 \%$ of patients), ethanolic ( $46 \%$ of patients) and other causes ( $8 \%$ of patients). The mean 


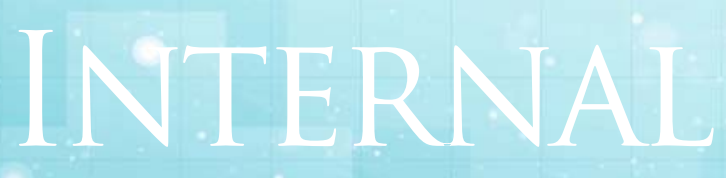

Original papers

length of hospitalization was $6.75 \pm 4.31$ days, most of the patients had a short length of hospital stay of under ten days, while only a few patients $(<10 \%)$ had a longer hospitalization, more than ten days (Figure 1). Majority of patients had interstitial AP and mortality within the study lot was $0 \%$. We evaluated the influence of age and environment upon the length of hospitalization, but there was no statistical significance.

We also analyzed if there were any correlations between blood cells and hematological ratios with length of hospitalization, but no significant association was obtained. In our study NLR didn't correlate with the severity of acute pancreatitis as defined by hospitalization duration ( $p=0.4840$ ), so we couldn't validate it as a prognostic tool.

A tendency of correlation between the level of glucose at admission and the length of hospitalization was noted (Figure 2). Serum glucose could be considered as a risk factor for the severity of acute pancreatitis, but our results did not reached statistical significance $((p=0.07)$, IC 95\%, 0.01(-0.01 - 0.02), r Pearson $=0.18$ ).

Also, a negative correlation between the level of alkaline phosphatase and hospitalization duration was observed in our study (Figure 3) ( $p=0.0259, r$ Pearson $=-0.28$ ). No other significance correlation was seen with respect to the other biochemical parameters evaluated in our patients (like C-reactive protein, bilirubin, transaminases, amylase, lipase).

Although we didn't notice any impact of NLR upon the length of hospitalization, as a risk factor for severity of acute pancreatitis, the value of this parameter was correlated with some biochemical parameters (Table 1 ).

\section{Discussion}

The assessment of severity of AP represents an important goal for our daily clinical practice. Throughout the years, many researchers have tried to evaluate the impact of several parameters used as prognostic factors for severity of AP. Nowadays, there isn't any simple score or parameter which can stratify the severity of disease upon admission of the patient.

In the current study, we assessed correlations of hematological and biochemical parameters with length of hospital stay, as a surrogate marker for AP severity. In contrast with some data in the literature, no significant correlation was seen for blood cell counts and ratios with hematological parameters with hospitalization duration in our study. However, serum glucose at admission and alkaline phosphatase proved to have a prognostic value with respect to length of hospital stay. 


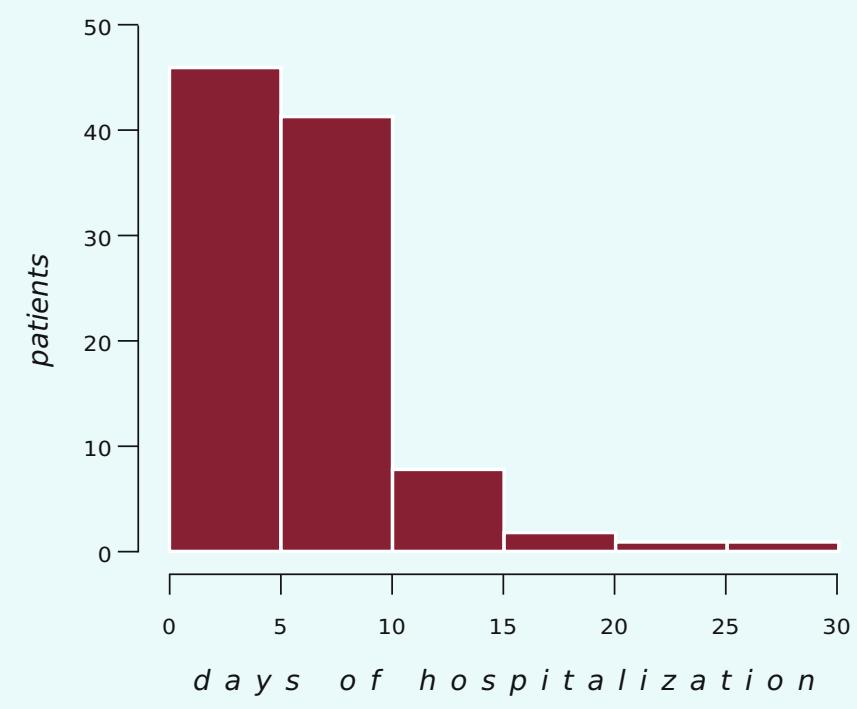

Figure 1. Distribution of length of hospitalization in the study group

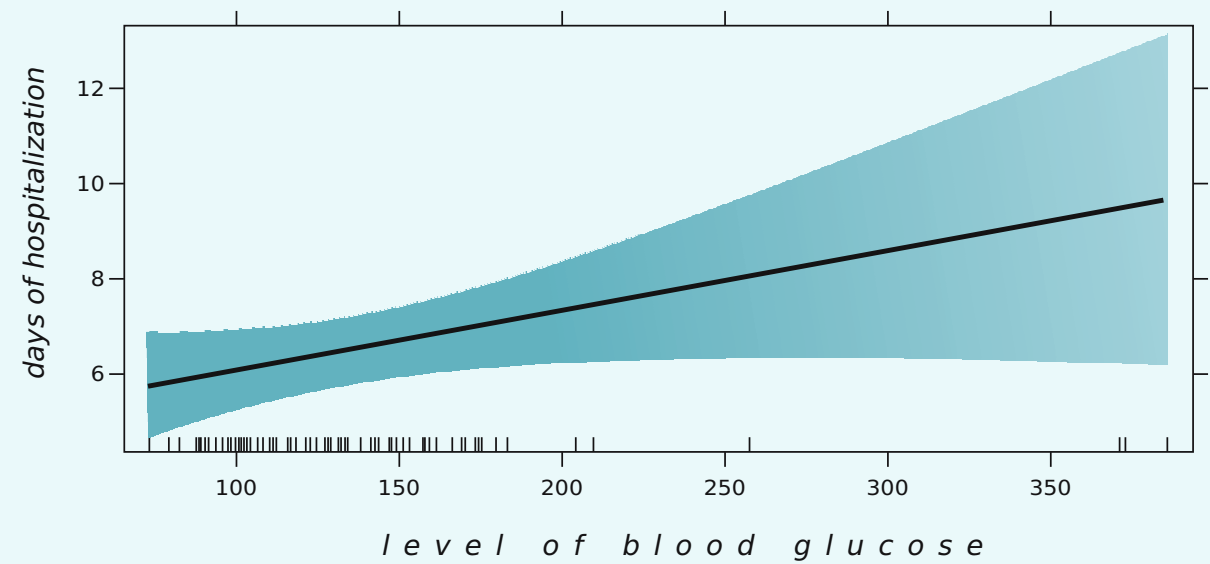

Figure 2. The impact of blood glucose to length of hospitalization

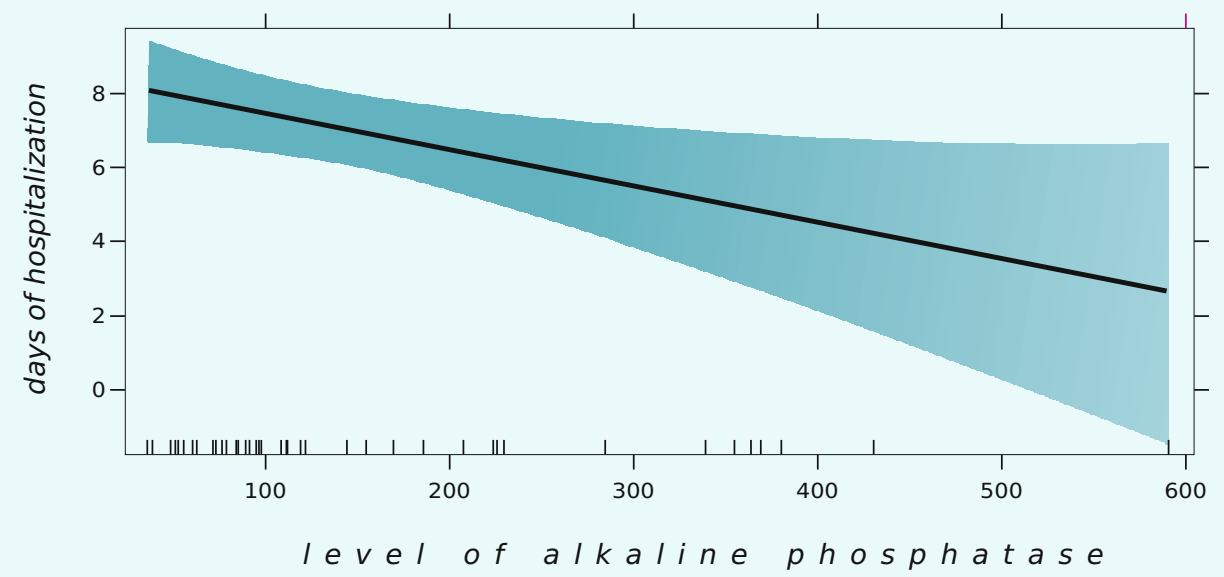

Figure 3. The impact of alkaline phosphatase to length of hospitalization 


\section{original papers}

\begin{tabular}{|c|c|}
\hline Biochemical parameter & $\begin{array}{c}\text { NLR } \\
\text { A Pearson (p value) }\end{array}$ \\
\hline Amylase & $\mathbf{0 . 2 2}(\mathbf{0 . 0 3 2 5})$ \\
\hline Fipase & $\mathbf{0 . 2 4}(\mathbf{0 . 0 1 6 2 )}$ \\
\hline C -eactive protein & $0.12(0.2634)$ \\
\hline Blood glucose & $0.17(0.1338)$ \\
\hline Creatinine & $\mathbf{0 . 2 2}(\mathbf{0 . 0 2 9 9 )}$ \\
\hline Total bilirubin & $0.16(0.1151)$ \\
\hline Conjugated bilirubin & $\mathbf{0 . 3 1}(\mathbf{0 . 0 0 2 3 )}$ \\
\hline AST & $\mathbf{0 . 3 4}(\mathbf{0 . 0 0 0 7 )}$ \\
\hline ALT & $0.12(0.2529)$ \\
\hline Glkaline phosphatase & $0.06(0.5266)$ \\
\hline Gama glutamyl transpeptidase & $0.22(0.0753)$ \\
\hline & $\mathbf{0 . 2 8}(\mathbf{0 . 0 1 1 9})$ \\
\hline
\end{tabular}

Table 1. Relationships between biochemical parameters and neutrophil-lymphocyte ratio

A number of observational studies has shown that hyperglycemia is associated with poor outcome in critically ill patients ${ }^{(21,22)}$. Zhao et al. have shown in retrospective study of 318 with acute pancreatitis that patients with diabetes mellitus had a longer hospitalization than patients without diabetes mellitus ${ }^{(23)}$. These data are consistent with those obtained in our study- the negative impact of hyperglycemia upon the severity of acute pancreatitis. Regarding the role of alkaline phosphatase in acute pancreatitis, there aren't enough studies which can demonstrate the importance of this parameter. Yin et al showed in a retrospective study with 1073 cases of acute pancreatitis that alkaline phosphatase level was negative correlated with hyperlipidemic acute pancreatitis ${ }^{(24)}$. Our results are consistent with his findings: patients with AP who had a longer hospitalization presented a low level of alkaline phosphatase. A low level of alkaline phosphatase could be associated with nonbiliary AP and the correlation seen in our 
study could in fact reflect a lower hospitalization duration for biliary AP, which is characterized by high levels of cholestatic enzymes. A decreased length of hospital stay for biliary AP could be explained by biliary passage with mild AP and referral of the patient for surgery. However, this proposed mechanism is not supported by a lack of similar correlation for GGT.

Concerning the NLR many studies had tried to evidence the role of this parameter as a prognostic tool for the severity of AP. Suppiah et al showed in a study of 146 patients with AP that an increased value of this parameter in the first 48 hours is associated with severe $A P^{(25)}$. Crisu et al observed in a recent study which compared a group with 100 patients with acute pancreatitis and a group with 30 healthy people that the value of NLR is increased in the group with AP $(p<0.05)^{(1)}$. Our study didn't evidence any impact of this parameter upon the severity of acute pancreatitis, as defined by the length of hospital stay.

Our study has several limitations: the small sample size and the disproportionate proportion of interstitial AP with favorable outcome (no fatalities, which precluded mortality to be used as the endpoint for severity.

\section{Conclusions}

Our results showed a tendency of hyperglycemia in patients with longer hospitalization, so this simple biochemical parameter could represent a prognostic tool for the severity of acute pancreatitis. Moreover, in our study patients with more days of hospitalization had a low level of alkaline phosphatase.

More studies are needed to further evaluate the prognostic value of routine hematological and biochemical parameters in early risk stratification of AP.

\section{References}

1. Crisu G, Atanasiu V, Marin F, Balaban V, Gaman L, Stoian I, Jinga M. Neutrophil to lymphocyte ratio and thrombocyte to lymphocyte ratio, new biochemical parameters in acute pancreatitis; Internal Medicine 2020, XVII, no.1;21-27.

2. Pratibha Anchi, Amit Khurana, Swarna Bale, Chandraiah Godugu. The Role of Plant-derived Products in Pancreatitis: Experimental and Clinical Evidence. Phytotherapy Research , 2017;31 (4), 591-623

3. Gaman L, Dorin D, Vlad A, Robu Gc, Radoi Mp, Stroica L, Badea M, Gilca M. Phytoceuticals in Acute Pancreatitis: Targeting the Balance between Apoptosis and Necrosis.Evidence- Based Complementary and Alternative Medicine, 2018 , (567);1-27

4. Alexandru Grigorovici, Cristian Velicescu, Delia Hinganu, Alina Calin, Marius Valeriu Hinganu, Dan Andronic - The Use of Neoprene in Experimental Pancreatitis. Revista de chimie ,Bucharest, 2019, 70 (2); 676-678

5. Nitsche C, Maertin S,Scheiber J, Ritter Ca, Lerch Mm, Mayerle J. Drug-induced pancreatitis. Curr Gastroenterol Rep 2012; 14: 131-8.

6. Bertilsson S, Kalaitzakis E. Acute pancreatitis and use of pancreatitis-associated drugs: a 10-year population-based cohort study. Pancreas 2015; 44: 1096-104.

7. Whitcomb DC. Genetic risk factors for pancreatic disorders. Gastroenterology 2013; 144: 1292-302

8. Cristina Serban, Mihaela Debita, Aurel Nechita, Dragos Voicu2, Mihaela Dumitru , Laura Rebegea, Dorel Firescu-Hypertriglyceridemia-Rare Etiological Condition of Necrotic Hemorrhagic Pancreatitis.Revista de chimie ,Bucharest, 2019; 70 (3); 1030-1032

9. Svetlana Igjatovic, Nada Majkic-Singh, Mihajlo Mitrovic, Miomir Gvozdenovic. Biochemical Evaluation of Patients with Acute Pancreatitis. Clin Chem Lab Med 2000; 38(11):1141-1144

10. Crisu G, Jinga M, Marin F, Gaman L, Balaban V, Ciora C, Atanasiu V. Biochemical parameters in acute pancreatitis. Research and science today, 2020, 1(19);125-131.

11. Lempinem M, Puolakkainen $P$, Kemppainen E..Clinical value of severity markers in acute pancreatitis. Scandinavian Journal of Surgery, 2005, 94:118123

12. Manrai M, Kochhar R, Gupta V, Yadav Td, Dhaka N, Kalra $N$ et al. Outcome of acute pancreatic and peripancreatic collections occurring in patients with acute pancreatitis. Ann Surg , 2018, 267 (2); 357-363. 


\section{INTERNAL}

Original papers

13. Vrolyk V, Wobeser Bk, Al-Dissi An, Carr A, Singh B. Lung inflammation associated with clinical acute necrotizing pancreatitis in dogs. Vet Pathol 2017; 54:129-40.

14. Tee Ys, Fang Hy, Kuo Im, Lin Ys, Huang Sf, Yu Mc. Serial evaluation of the SOFA score is reliable for predicting mortality in acute severe pancreatitis. Medicine (Baltimore) 2018;97(7):e9654

15. Juneja D, Gopal Pb, Ravula M. Scoring systems in acute pancreatitis: which one to use in intensive care units? J Crit Care 2010;25:358.e9-15.

16. Hagjer S, Kumar N.Evaluation of the BISAP scoring system in prognostication of acute pancreatitisaprospective observational study. Int J Surg 2018;54(Pt A):76-81.

17. Gao W, Yang Hx, Ma Ce. The value of BISAP score for predicting mortality and severity in acute pancreatitis: a systematic review and meta-analysis. PLoS One 2015;10:e0130412.

18. Suppiah A, Malde D, Arab T, Hamed M, Allgar V, Smith Am, Morris-Stiff $G$. The prognostic value of the neutrophil-lymphocyte ratio (NLR) in acute pancreatitis: identification of an optimal NLR. J Gastrointest Surg 2013;17:675-81.

19. Cho Sk, Jung S, Lee Kj, Kim Jw. Neutrophil to lymphocyte ratio and platelet to lymphocyte ratio can predict the severity of gallstone pancreatitis. BMC
Gastroenterol 2018;18:18.

20. Tsuang $w$, navaneethan $u$, ruiz l, palascak j.b.,gelrud A. Hypertriglyceridemic pancreatitis: presentation and management, Am. J. Gastroenterol.2009, 104 (4) :984991

21. Egi M, Bellomo R, Stachowski E, French CJ, Hart GK, Hegarty C, Bailey M. Blood glucose concentration and outcome of critical illness: the impact of diabetes. Crit Care Med 2008; 36: 2249-2255

22. Whitcomb BW, Pradhan EK, Pittas AG, Roghmann MC, Perencevich EN. Impact of admission hyperglycemia on hospital mortality in various intensive care unit populations. Crit Care Med 2005; 33: 2772-2777

23. Zhao $X$, Chang Mei $H$, Chen L, Jiang $L, H e M$, Chen J, Hu Z, Ye H, Hu H, Zhou L, Li Y, Hu R. An increased level of haemoglobin AlC predicts a poorer clinical outcome in patients with acute pancreatitis. Clin Endocrinol (Oxf) 2012; 77: 241-245

24. Yin G, Cang X, Yu G, Hu G, NiJ, XiongJ et al . Different Clinical Presentations of Hyperlipidemic Acute Pancreatitis: A Retrospective Study.Pancreas Journal.2015; 44(7):1105-10.

25. Suppiah A, Malde D, Arab T, Hamed M, Allgar V, Smith $A M$ et al. The prognostic value of neutrophillymphocyte ratio (NLR) in acute pancreatitis. Identification of an optimal NLR. J Gastrointestinal Surg 2013; 17 (4):675-81 